\title{
Stress-tolerant antagonistic rhizobacteria isolated from the medicinal plant Tinospora cordifolia
}

\author{
Pratibha Vyas *, AMANDEeP KaUR \\ Department of Microbiology, School of Bioengineering and Biosciences, \\ Lovely Professional University, Phagwara, Punjab, India
}

\begin{abstract}
Medicinal plants harbor a large number of beneficial microorganisms. Stress tolerance is an important attribute while screening bacteria for developing microbial inoculants. In the present studies, salt-tolerant bacteria isolated from the rhizosphere of the medicinal plant Tinospora cordifolia were screened for multiple plant growth promoting activities, antagonism against fungal pathogens and stress tolerance. A total of 25 morphologically distinct salt-tolerant bacteria were isolated on nutrient agar plates with $2.5 \% \mathrm{NaCl}$ from the rhizosphere of Tinospora cordifolia growing in Jalandhar, Punjab, India. Twelve salt-tolerant bacterial isolates showing phosphate solubilization zones ranging from 3-12 mm on modified Pikovskaya agar were screened for the production of auxins, 1-aminocuclopropane 1-carboxylate (ACC) deaminase, ammonia and hydrogen cyanide. Of these 12 salt-tolerant and phosphate-solubilizing isolates, auxin production was shown by all isolates, ACC-deaminase activity by 7 isolates, ammonia production by 8 isolates and hydrogen cyanide (HCN) by 5 isolates. Phosphate solubilization in liquid medium ranged from 26 to $151 \mu \mathrm{g} / \mathrm{ml}$, while auxin production ranged 10.7 to $31 \mu \mathrm{g} / \mathrm{ml}$. Five bacterial isolates showing all plant growth-promoting activities were screened for antagonism against the phytopathogens $\mathrm{Fu}$ sarium moniliforme, Fusarium verticillioides, Curvularia lunata and Alternaria alternata and the abiotic stress conditions of salinity, temperature, $\mathrm{pH}$ and calcium salts. The bacterial isolate $\mathrm{T} 1 \mathrm{~B} 1$, which shows multiple plant growth promoting activities and stress tolerance, was identified as Bacillus sp. based on phenotypic characteristics and 16S rRNA gene sequencing. The bacterial isolate T1B1 was selected as a potential candidate for the development of microbial inoculants for stressed environments.
\end{abstract}

Key words: ACC deaminase, auxin production, antagonism, phosphate solubilization, stress tolerance, Tinospora cordifolia

\section{Introduction}

Excessive use of chemical fertilizers and pesticides for increasing agricultural productivity has disturbed the delicate ecological balance (Aktar et al., 2009). In view of the large-scale use of fertilizers, interest has increased in finding safe and eco-friendly alternatives for improving productivity in agriculture. Plant growth-promoting bacteria residing in the rhizosphere of plants have been reported to enhance plant growth by various mechanisms including nitrogen fixation, phosphate solubilization, production of phytohormones, 1-amino-cyclopropane 1-carboxylate (ACC) deaminase activity, siderophore production, and ammonia production and by in- hibiting phytopathogens (Gulati et al., 2008; Gulati et al., 2009; Vyas and Gulati, 2009). It has also been reported that these rhizobacteria help plants tolerate abiotic stresses such as alkalinity, salinity and nutrient deficiencies (Glick, 2014; Habib et al., 2016).

Different biotic and abiotic factors affect the performance of microorganisms (Vyas et al., 2010; Das et al., 2015). Abiotic stresses include temperature, $\mathrm{pH}$, moisture status, salinity and salts present in soils. Importantly, even though many plant growth-promoting rhizobacteria show good results in vitro, they fail to give the same results in fields, when applied as microbial inoculants. One main reason for their failure is the stress im-

\footnotetext{
* Corresponding author: Microbiology Domain, School of Bioengineering and Biosciences, Lovely Professional University, Jalandhar-Delhi GT Road, Phagwara-144411, Punjab, India; e-mail: pratibha.19064@lpu.co.in; vyasp2000@yahoo.co.in
} 
posed on them by sudden changes in the environment (Praveen Kumar et al., 2014). Therefore, screening for stress tolerance is an important parameter in the selection of bacterial strains for the development of microbial inoculants. Many bacteria have adapted themselves to the fluctuations in the temperature, $\mathrm{pH}$ and osmolarity encountered while living in stressed environments. To date, however, limited reports are available on the selection of bacterial strains based on stress tolerance for the development of microbial inoculants (Rangarajan et al., 2002; Sharan et al., 2008; Vyas et al., 2009; Vyas et al., 2010). One possible future approach is to select stress tolerant bacteria with multiple plant growth-promoting activities.

Tinospora cordifolia is an important multipurpose medicinal plant with the common name Giloy, and it is used as a bitter tonic to treat diabetes, skin infections, irritability and dysenteric diseases (Mittal et al., 2014). It is a herbaceous, deciduous, and glabrous plant growing throughout India and described as "Amrita" in the classical literature of the ayurvedic system of medicine. It can be used as a source of anticancer, antiviral, antiallergic and anti-inflammatory agents. To date no reports are available on the isolation of stress-tolerant rhizobacteria from Tinospora cordifolia. So, as a first step in the development of microbial inoculants, the present studies were designed to isolate stress-tolerant rhizobacteria from the medicinal plant Tinospora cordifolia growing in Jalandhar, Punjab, India and to screen them for plant growth-promoting activities.

\section{Materials and methods}

\section{Soil sampling}

Rhizospheric soil samples were collected from the medicinal plant Tinospora cordifolia growing in Jalandhar, Punjab, India. From each plant, a sample was collected by digging soil up to $10-12 \mathrm{~cm}$ depth at 2 spots around each plant. Three composite soil samples prepared by mixing 4 soil samples collected from 2 different plants were employed for the isolation of salt-tolerant bacteria.

\section{Isolation of salt-tolerant rhizobacteria}

For the isolation of salt-tolerant rhizobacteria, serial soil dilutions were spread plated on nutrient agar plates with $2.5 \% \mathrm{NaCl}$. The plates were incubated at $28^{\circ} \mathrm{C}$ for $48 \mathrm{~h}$. The bacterial colonies, which were morphologically distinct from one another, were purified by streaking on nutrient agar plates and stocked in 30\% glycerol (w/v) until further use.

\section{Screening for plant growth-promoting attributes}

\section{Phosphate solubilization}

Qualitative screening for phosphate solubilization by salt-tolerant bacterial isolates was performed on modified Pikovskaya (PVK) agar with tricalcium phosphate (Gupta et al., 1994). Zones of phosphate solubilization around bacterial colonies were measured at $28^{\circ} \mathrm{C}$ on day 5 of incubation. Quantitative estimation was conducted by growing the bacteria in National Botanical Research Institute Phosphate (NBRIP) broth containing 0.5\% tricalcium phosphate using the vanado molybdate yellow color method after 5 days of incubation, as described earlier (Nautiyal, 1999; Gulati et al., 2008). The amounts of liberated phosphorus were expressed as micrograms per $\mathrm{ml}$ over uninoculated controls.

\section{Production of indole-3-acetic acid}

To test the production of indole-3-acetic acid, the bacterial isolates were grown at $28^{\circ} \mathrm{C}$ for $48 \mathrm{~h}$ in a nutrient broth containing 0.1\% DL-tryptophan using Salkowski reagent and then analyzed spectrophotometrically at $535 \mathrm{~nm}$ (Loper and Schroth, 1986). The values of IAA-like auxins were expressed as micrograms per $\mathrm{ml}$ over uninoculated controls.

\section{1-aminocyclopropane-1-carboxylate (ACC)-deaminase activity}

Screening of bacterial isolates for 1-aminocyclopropane-1-carboxylate (ACC)-deaminase activity was done on DF salts minimal medium with ACC as the sole nitrogen source (Jacobson et al., 1994). The isolates were streaked on plates and incubated at $28^{\circ} \mathrm{C}$ for $48 \mathrm{~h}$. Growth appearing on the Petri plates indicated ACC-deaminase activity.

\section{Ammonia production}

Ammonia production by bacterial isolates was detected by a change in color from faint yellow to dark brown after the addition of Nessler's reagent to 24 h-old bacterial culture grown in peptone broth (Cappuccino and Sherman, 1992).

\section{Hydrogen cyanide production}

Hydrogen cyanide (HCN) production was detected following the Castric method (1975). Bacterial cultures 
were streaked on nutrient agar amended with glycine. A Whatman filter paper soaked in $2 \% \mathrm{Na}_{2} \mathrm{CO}_{3}$ in $0.5 \%$ picric acid solution was kept inside the lid of the Petri plate and incubated at $28^{\circ} \mathrm{C}$ for 3 days. A change in the color of the filter paper disks from orange to brown indicated $\mathrm{HCN}$ production.

\section{Antagonism against fungal phytopathogens}

The bacterial isolates were evaluated on yeast extract medium by dual culture plate assay (as described earlier) for the possession (or not) of antagonistic activities against the fungal phytopathogens Fusarium moniliforme strain 1100 (MTCC 156), Fusarium verticillioides strain 1 (MTCC 3322), Curvularia lunata strain 716 (MTCC 283) and Alternaria alternata strain 6663 (MTCC 1362) (Kaur et al., 2017).

\section{Screening for stress tolerance}

Screening for stress tolerance was performed by growing the salt-tolerant bacterial isolates at different stress levels according to temperature, $\mathrm{pH}$, salinity and calcium salts. The bacterial isolates were streaked on nutrient agar plates and incubated at 10,30 and $40^{\circ} \mathrm{C}$ for $48 \mathrm{~h}$ and observed for growth. Similarly, for $\mathrm{pH}$ stress, the isolates were grown on nutrient agar with $\mathrm{pH} 5,7$, and 9. Likewise, for salinity stress, the bacterial isolates were grown on nutrient agar with $5 \%$ and $7 \% \mathrm{NaCl}$. The bacterial isolates were also screened for tolerance against calcium salts by being grown on nutrient agar plates with the addition of $2.5 \%$ and $5 \% \mathrm{CaSO}_{4}, 2.5 \%$ and $5 \% \mathrm{CaCl}_{2}$, and $2.5 \%$ and $5 \% \mathrm{CaCO}_{3}$.

For desiccation tolerance, $20 \%$ and $30 \%$ polyethylene glycol (PEG) 6000 were added to nutrient broths, as previously described (Vyas et al., 2009). The medium was inoculated with overnight grown bacterial cultures and incubated at $30^{\circ} \mathrm{C}$ for 5 days in a shaking incubator at 180 revolutions per minute. Viable cells were counted on day 5 by spread plating on nutrient agar plates of dilutions ranging from $10^{-2}$ to $10^{-6}$ of each sample. The results are expressed as $\mathrm{CFU} / \mathrm{ml}$ per sample.

\section{Characterization and identification of the bacterial isolate}

The bacterial isolate was initially characterized based on phenotypic features including Gram staining, motility, endospore formation, MR-VP test, and citrate, catalase, oxidase and urease tests following the standard methods (Krieg and Holt, 1984).
For 16S rRNA gene sequencing, DNA was isolated using the DNeasy Plant Mini Kit (Qiagen). The amplification of 16S rRNA genes was performed using the universal primers fD1 (5'-AGA GTT TGA TCC TGG CTC AG-3') and rP2 (3'-ACG GCT ACC TTG TTA CGA CTT-5') (Weisburg et al., 1991). The method used for amplification of the gene, thermocycling conditions, cloning, and sequence analysis was performed as described earlier (Gulati et al., 2008). The sequences were aligned with ClustalW. MEGA software package version 7 using Kimura's two-parameter model was used to calculate the evolutionary distance of the bacterial T1B1 strain and its related taxa.

\section{Experimental design and statistical analysis}

A randomized block design was adopted for carrying out the experiments. All values are means of 3 replicates, unless stated otherwise.

\section{Results and discussion}

\section{Isolation of stress tolerant rhizobacteria}

Large-scale use of chemical fertilizers and pesticides has polluted the environment. Safe and eco-friendly alternatives are required to enhance agricultural production to feed ever increasing populations. Plant growth-promoting rhizobacteria are important components of sustainable agriculture and have been reported to enhance plant growth (Gulati et al., 2010; Vyas and Gulati, 2009; Vyas et al., 2010). However, the performance of such bacteria in a natural environment is affected by stress conditions, thereby limiting the use of these microorganisms as bioinoculants. Most of the plant growthpromoting rhizobacteria (PGPR) have been tested to give good results under controlled environmental conditions but have failed to show the same effects in field conditions.

Stress-tolerant bacteria have been isolated in earlier attempts from various sources; however, there are no reports available on the rhizobacteria obtained from the rhizosphere of Tinospora cordifolia (Vyas et al., 2009; Ashwitha et al., 2013; Panwar et al., 2016). Recently, plant growth-promoting and antagonistic endophytic Pseudomonas sp. has been identified from soil samples of Tinospora cordifolia (Kaur et al., 2017). Herein, a total of 25 morphologically distinct salt-tolerant bacteria were isolated by spread plating serial dilutions on 
Table 1. Plant growth-promoting activities of salt-tolerant bacteria from Tinospora cordifolia rhizobacteria

\begin{tabular}{l|c|c|c|c|c}
\hline \multicolumn{1}{|c|}{ Isolates } & $\begin{array}{c}\text { TCP solubilization } \\
{[\mu \mathrm{g} / \mathrm{ml}]}\end{array}$ & $\begin{array}{c}\text { Auxin production } \\
{[\mu \mathrm{g} / \mathrm{ml}]}\end{array}$ & $\begin{array}{c}\text { Ammonia } \\
\text { production }\end{array}$ & $\begin{array}{c}\text { ACC deaminase } \\
\text { activity }\end{array}$ & $\begin{array}{c}\text { HCN } \\
\text { production }\end{array}$ \\
\hline T1B1 & $151.3 \pm 1.20$ & $31.3 \pm 2.60$ & +++ & ++ & +++ (strong) \\
\hline T1B2 & $102.3 \pm 1.85$ & $27.7 \pm 2.18$ & + & + & - \\
\hline T1B12 & $87.7 \pm 1.45$ & $26.7 \pm 1.20$ & ++ & + & - \\
\hline T2B4 & $28.0 \pm 1.73$ & $20.3 \pm 1.67$ & - & - & - \\
\hline T2B5 & $32.7 \pm 1.76$ & $10.7 \pm 1.20$ & + & +++ & + (moderate) \\
\hline T2B8 & $127.0 \pm 2.64$ & $27.0 \pm 1.52$ & +++ & - & + \\
\hline T2B13 & $54.0 \pm 1.53$ & $18.7 \pm 2.02$ & - & ++ & + (moderate) \\
\hline T2B14 & $86.7 \pm 1.86$ & $21.0 \pm 1.52$ & +++ & + & + (weak) \\
\hline T3B2 & $132.0 \pm 1.15$ & $24.0 \pm 2.08$ & ++ & + & + (weak) \\
\hline T3B3 & $121.0 \pm 1.52$ & $19.7 \pm 0.88$ & ++ & - & - \\
\hline T3B7 & $26.3 \pm 1.45$ & $13.0 \pm 1.63$ & - & - & - \\
\hline T3B10 & $49.7 \pm 1.85$ & $15.0 \pm 1.63$ & - & + & + \\
\hline
\end{tabular}

Values are the mean of 3 replicates \pm SE mean. ++++ - luxuriant growth, ++ - good growth, + - poor growth, - it is no growth/no activity

nutrient agar plates containing $2.5 \% \mathrm{NaCl}$. The salt-tolerant bacteria were further assessed for plant growthpromoting activities, including phosphate solubilization, auxin production, ACC deaminase activity, ammonia production and $\mathrm{HCN}$ production.

\section{Screening for plant growth-promoting activities}

Out of 25 salt-tolerant bacteria, 12 isolates showed phosphate solubilization zones ranging from 2 to $14 \mathrm{~mm}$ on modified Pikovskaya agar on day 5 of incubation at $28^{\circ} \mathrm{C}$. The highest zone was produced by the T1B1 isolate and the lowest by T2B5. In NBRIP broth, phosphate solubilization ranged from $26 \mu \mathrm{g} / \mathrm{ml}$ by T3B7 to $151 \mu \mathrm{g} / \mathrm{ml}$ by T1B1 on day 5 of incubation (Table 1).

The rhizosphere of plants contains tryptophan from root exudates, which is used by bacteria for the production of auxins. IAA production in the presence of tryptophan has been reported for many PGPR (Tsavkelova et al., 2007; Vyas et al., 2010). Herein, all 12 salt-tolerant bacteria showing phosphate solubilization properties also produced IAA after $48 \mathrm{~h}$ of incubation, as measured using Salkowski reagent. Auxin production between bacterial strains ranged from 10.7 to $31.3 \mu \mathrm{g} / \mathrm{ml}$ (Table 1). Maximum auxin production was achieved by T1B1, while the minimum by T2B5.

Several plant growth-promoting bacteria produce 1-aminocyclopropane-1-carboxylate (ACC) deaminase, which cleaves the plant ethylene precursor ACC to $\alpha$-ketobutyrate and ammonia, thereby lowering the level of ethylene in the rhizosphere (Glick, 2014). The bacteria producing ACC-deaminase are known to promote root elongation and plant growth by hydrolyzing ACC from germinating seeds, thereby lowering ethylene levels and increasing the active rhizosphere zone (Glick, 2014; Farajzadeh et al., 2010). Several researchers have exploited the ability of bacteria to utilize ACC as sole source of nitrogen in the screening of ACC-deaminase producing bacteria (Penrose and Glick, 2003; Dey et al., 2004; Glick, 2014). In the present studies, 7 isolates exhibited growth on DF salts minimal medium with ACC as sole nitrogen source, of which only 3 bacterial strains showed luxuriant growth and 6 showed good growth (Table 1). The growth of the bacterial isolates on DF medium with $\mathrm{ACC}$ as sole nitrogen source indicated that these strains showed ACC-deaminase activity. ACCdeaminase producing plant growth-promoting bacteria are known to protect plants against drought, flooding, salts, and heavy metals as well as bacterial and fungal pathogens (Glick 2014; Wang et al., 2016). Therefore, bacteria producing ACC deaminase are important components of agriculture in stressed environments.

Ammonia production is also an important trait, as it is used by plants for their growth as a source of nitrogen (Ahmad et al., 2008). Ammonia was produced by 8 isolates, while hydrogen cyanide by 5 (Table 1 ). 
Table 2. Growth of salt-tolerant rhizobacteria from Tinospora cordifolia at different salinity and calcium salt levels

\begin{tabular}{l|c|c|c|c|c|c|c|c}
\hline \multirow{2}{*}{ Isolate } & \multicolumn{2}{|c|}{$\mathrm{NaCl}(\%)$} & \multicolumn{2}{c|}{$\mathrm{CaSO}_{4}(\%)$} & \multicolumn{2}{c|}{$\mathrm{CaCl}_{2}(\%)$} & \multicolumn{2}{c}{$\mathrm{CaCO}_{3}(\%)$} \\
\cline { 2 - 9 } & 5 & 7 & 2.5 & 5 & 2.5 & 5 & 2.5 & 5 \\
\hline T1B1 & +++ & + & +++ & +++ & +++ & ++ & ++ & + \\
\hline T2B8 & +++ & +++ & +++ & ++ & + & - & +++ & ++ \\
\hline T2B14 & +++ & ++ & ++ & + & - & - & +++ & ++ \\
\hline T3B2 & +++ & + & +++ & ++ & ++ & - & +++ & +++ \\
\hline T3B3 & +++ & ++ & +++ & +++ & ++ & - & ++ & - \\
\hline
\end{tabular}

+++ - good growth, ++ - medium growth, - it is no growth

Table 3. Growth of salt-tolerant rhizobacteria from Tinospora cordifolia at different $\mathrm{pH}$ and temperature levels

\begin{tabular}{l|c|c|c|c|c|c}
\hline \multirow{2}{*}{ Isolate } & \multicolumn{4}{|c|}{$\mathrm{pH}$} & \multicolumn{3}{c}{ Temperature $\left({ }^{\circ} \mathrm{C}\right)$} \\
\cline { 2 - 7 } & 5 & 7 & 9 & 10 & 30 & 40 \\
\hline T1B1 & ++ & +++ & ++ & ++ & +++ & + \\
\hline T2B8 & - & +++ & ++ & - & +++ & ++ \\
\hline T2B14 & + & +++ & - & - & +++ & - \\
\hline T3B2 & - & +++ & ++ & ++ & +++ & - \\
\hline T3B3 & ++ & +++ & ++ & - & +++ & + \\
\hline
\end{tabular}

+++- good growth, ++ - medium growth, - it is no growth

\section{Antagonistic activity against fungal phytopathogens}

Five bacterial isolates showing all plant growth-promoting activities were tested in a dual plate assay against 4 phytopathogenic fungi including Alternaria alternata, Fusarium moniliforme, Curvularia lunata and Fusarium verticillioides. Fusarium species are well-known human, animal and plant pathogens. Fusarium oxysporum and Curvularia lunata cause diseases in a wide range of plant species belonging to different families (Lal et al., 2013). Similarly, Alternaria alternata has a wide host range and causes leaf spots and blights in many plants, while $F u$ sarium verticillioides is an fungal pathogen reported to cause stalk rot, ear rot and kernel rot in corn (MurilloWilliams and Munkvold, 2008; Ghosh et al., 2016). In the present studies, the bacterial isolates showed $20-40 \%$ inhibition of Alternaria alternata, 15-32\% inhibition of Fusariummoniliforme, 10-28\% inhibition of Curvularia lunata, and $12-25 \%$ inhibition of Fusarium verticillioides. The highest antagonistic activity against all tested pathogens was shown by T1B1, while the lowest by T3B3. The antagonistic activity shown by 5 bacterial isolates can be correlated with the production of $\mathrm{HCN}$, as all strains exhibited strong to weak $\mathrm{HCN}$ production (Table 1). The highest activity was shown by T1B1 (high HCN production rate) as compared with T3B3, which produced small amounts of $\mathrm{HCN}$ (Table 1). Among the volatile compounds produced by $\mathrm{PGPR}, \mathrm{HCN}$ is one of the most important compounds inhibiting the growth of fungal pathogens (Reetha et al., 2014).

\section{Screening for stress tolerance}

The performance of plant growth-promoting microorganisms is constrained by the stress generated by environmental factors including moisture status, temperature, desiccation, $\mathrm{pH}$, alkalinity/acidity and salinity in the soil (Rangarajan et al., 2002; Vyas et al., 2010; Das et al., 2015). Therefore, the selection of stress-tolerant bacterial strains is essential for consistency in field performance for application as microbial inoculants. Five salttolerant bacterial isolates showing all plant growth-promoting activities and antagonism against fungal pathogens were screened for tolerance against temperature, $\mathrm{pH}$, sa- 
linity and calcium salts (Table 2 and Table 3 ). All bacterial isolates showed growth on agar medium with $5 \%$ and $7 \%$ $\mathrm{NaCl} ; 2.5 \%$ and $5 \% \mathrm{CaSO}_{4}$ and $2.5 \%$ and $5 \% \mathrm{CaCO}_{3}$, except T3B3 which did not grow on $5 \% \mathrm{CaCO}_{3}$. All isolates grew on $2.5 \% \mathrm{CaCl}_{2}$, except T2B14, while none, except one T1B1 (moderate growth), grew on $5 \% \mathrm{CaCl}_{2}$ (Table 2).

The bacterial isolates had different tolerances to $\mathrm{pH}$ and temperature (Table 3). Similar results have previously been observed during the screening of stresstolerant Pseudomonas strains from the Lahaul and Spiti valleys in Himachal Pradesh, India (Vyas et al., 2009). All bacterial strains isolated in this research grew on agar at $\mathrm{pH} 7$ and $30^{\circ} \mathrm{C}$. All isolates, except for T2B14, grew on agar at $\mathrm{pH} 9$, while only 3 on agar at $\mathrm{pH} 5$. Two isolates (T1B1 and T3B2) were able to grow at $10^{\circ} \mathrm{C}$, while 3 isolates (T1B1, T2B8 and T3B3) showed growth at $40^{\circ} \mathrm{C}$. Many rhizobacteria have earlier been reported as possessing plant growth-promoting activities, but only limited reports are available where bacteria have been screened for stress tolerance, along with other activities. Screening for tolerance to $\mathrm{pH}$, temperature and desiccation is important when selecting stress-tolerant bacteria (Vyas et al., 2009).

Bacterial isolate T1B1, which shows the highest stress tolerance, was screened for desiccation tolerance using $20 \%$ and $30 \%$ PEG 6000 . The colony forming units per milliliter $(\mathrm{CFU} / \mathrm{ml})$ of the isolate decreased with increases in PEG 6000 concentration. The T1B1 isolate exhibited CFU of $3.3 \times 10^{7}$ and $2.1 \times 10^{5}$ per $\mathrm{ml}$ in $20 \%$ and $30 \%$ PEG, respectively, on day 5 of incubation.

The results for desiccation tolerance indicated that the T1B1 isolate could be used as a bioinoculant in areas prone to drought, as it tolerated up to 30\% PEG 6000. Similar results were observed in an earlier study, which showed the importance of desiccation and temperature on the survivability of bacteria (Vyas et al., 2009). Therefore, bacterial isolates should be screened for tolerance to desiccation when selecting them for the development of microbial inoculants.

\section{Characterization and identification of bacterial isolate T1B1}

Bacterial isolate T1B1 was Gram positive, motile, rod-shaped, arranged in chains, and positive for endospore, catalase and citrate utilization. The isolate tested negative for oxidase, methyl red, Voges Proskauer, indole and urease. The genera Bacillus, Clostridium and

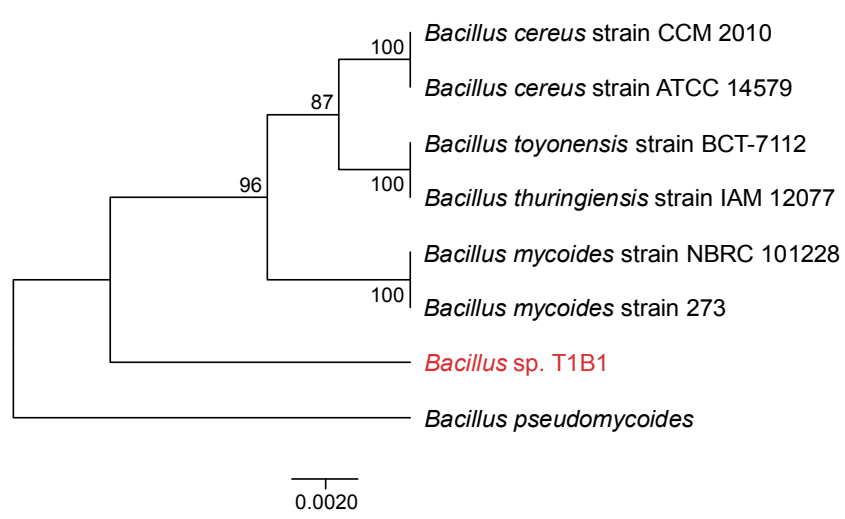

Fig. 1.Phylogenetic tree constructed based on 16S rRNA gene sequences of T1B1 and its nearest neighbors using the neighbor-joining method

Sporosarcina produce endospores. Bacterial isolate T1B1 returned a positive catalase test, so the possibility that this bacterium falls within the genus Clostridium was ruled out. Likewise, since T1B1 is rod-shaped, it could not fall in the genus Sporosarcina as this genus is characterized by a coccus shape arranged in packets (Krieg and Holt, 1984). The genus Bacillus is characterized as Gram positive, with motile rods arranged in short or long chains, oxidase negative and catalase positive. Therefore, based on the results, bacterial isolate T1B1 was tentatively identified as Bacillus sp.

To confirm the identity of bacterial isolate T1B1, 16S rRNA gene sequencing was carried out. 16S rRNA gene is the most commonly used marker for inferring the phylogenetic relationship among bacteria, due to its universal distribution, highly conserved nature, and the fundamental role of the ribosome in protein synthesis, non-horizontal transfer and its rate of evolution (Stackebrandt and Goebel, 1994; Wang et al., 2007). 16S rRNA gene analysis of a 1456-bp partial sequence of T1B1 showed $99 \%$ homology with Bacillus cereus ATCC $14579^{(\mathrm{T})}$ (Fig. 1). The phylogenetic tree constructed based on 16S rRNA gene sequences of T1B1 and its nearest neighbors from the NCBI GenBank showed 5 distinct groups with T1B1 forming an outgroup (Fig. 1). Therefore, the bacterial isolate was identified as Bacillus sp. Previously, 4 drought-tolerant Bacillus spp. from the rhizospheres of different crops had been identified as Bacillus amyloliquifaciens, $B$. licheniformis, $B$. thuriengiensis and $B$. subtilis based on 16S rRNA gene sequencing (Vardharajula et al., 2011). 


\section{Conclusions}

In the present studies, a bacterial isolate T1B1 identified as Bacillus sp. was tested and selected as a potential candidate to be used as a microbial inoculant for plants growing in a stressed environment. The isolate showed tolerance toward all tested stresses. Moreover, it exhibited multiple plant growth-promoting activities. To the best of our knowledge, this is the first report on stress-tolerant plantgrowth-promoting antagonistic rhizobacteria isolated from soil samples where Tinospora cordifolia grows.

\section{Acknowledgements}

The authors are grateful to the Chancellor and Pro-Chancellor, Lovely Professional University, Punjab for providing the necessary facilities and financial support to carry out these research studies.

\section{References}

Aktar M.W., Sengupta D., Chowdhury A. (2009) Impact of pesticides use in agriculture: their benefits and hazards. Interdis. Toxicol. 2: 1-12.

Ahmad F., Ahmad I., Khan M.S. (2008) Screening of free-living rhizospheric bacteria for their multiple plant growthpromoting activities. Microbiol. Res. 163: 173-181.

Ashwitha K., Rangeshwaran R., Vajid N.V., Sivakumar, G., Jalali S.K., Rajalaksmi K., Manjunath H. (2013) Characterization of abiotic stress tolerant Pseudomonas spp. occurring in Indian soils. J. Biol. Control. 27(4): 319-328.

Castric P.A. (1975) Hydrogen cyanide a secondary metabolite of Pseudomonas aeruginosa. Can. J. Microbiol. 21: 613 $-618$

Cappuccino J.C., Sherman N. (1992) Microbiology: a Laboratory Manual. Benjamin/Cummings Publ. Co., New York: 125-179.

Das P., Behera1 B.K., Meena D.K., Azmi S.A., Chatterjee S., Meena M., Sharma A.P. (2015) Salt stress tolerant genes in halophilic and halotolerant bacteria: Paradigm for salt stress adaptation and osmoprotection. Inter. J. Curr. Microbiol. App. Sci. 4: 642-658.

Dey R., Pal K.K., Bhatt D.M., Chauhan S.M. (2004) Growth promotion and yield enhancement of peanut (Arachis hypogaea L.) by application of plant growth promoting rhizobacteria. Microbiol. Res. 159: 371-394.

Farajzadeh D., Aliasgharzad N., Bashir N.S., Yakhchali B. (2010) Cloning and characterization of a plasmid encoded ACC deaminase from an indigenous Pseudomonas fluorescens FY32. Curr. Microbiol. 61: 37-43.

Ghosh R., Barman S., Khatun J., Mandal N.C. (2016) Biological control of Alternaria alternata causing leaf spot disease of Aloe vera using two strains of rhizobacteria. Biol. Control. 97: 102-108.
Glick B.R. (2014) Bacteria with ACC deaminase can promote plant growth and help to feed the world. Microbiol. Res. 169: 30-39.

Gulati A., Rahi P., Vyas P. (2008) Characterization of phosphate solubilizing fluorescent pseudomonads from rhizosphere of seabuckthorn growing in cold deserts of Himalayas. Curr. Microbiol. 56: 73-79.

Gulati A., Vyas P., Rahi P., Kasana R.C. (2009) Plant growth promoting and rhizosphere competent Acinetobacter rhizosphaerae strain BIHB 723 from the cold deserts of Himalayas. Curr. Microbiol. 58: 371-377.

Gulati A., Sharma N., Vyas P., Sood S., Rahi P., Pathania V., Prasad R. (2010) Organic acid production and plant growth promotion as a function of phosphate solubilization by Acinetobacter rhizosphaerae from the cold deserts of the trans-Himalayas. Arch. Microbiol. 192: 975-983.

Gupta R., Singal R., Shanker A., Kuhad R.C., Saxena R.K. (1994) A modified plate assay for screening phosphatesolubilizing microorganisms. J. Gen. App. Microbiol. 40: 255-260.

Habib S.H., Kausar H., Saud H.M. (2016) Plant growth-promoting rhizpobacteria enhance salinity stress tolerance in Okra through ROS-scavenging enzymes. BioMed Res. International. doi.org/10.1155/2016/6284547.

Jacobson B.C., Pasternak J.J., Glick B.R. (1994) Partial purification and characterization of 1-aminocyclopropane-1carboxylate deaminase from the plant growth-promoting rhizobacterium Pseudomonas putida GR 12-2. Can. J. Microbiol. 40: 1019-1025.

Kaur R., Devi M.A., Vyas P. (2017) Endophytic Pseudomonas sp. TCA1 from Tinospora cordifolia stem with antagonistic and plant growth-promoting potential. Res. J. Pharmacy Technol.10(2): 456-460.

Krieg N.R., Holt J.G. (1984) Bergey's Manual of Systematic Bacteriology. Williams and Willkins, Baltimore: vol. 1: 964.

Lal M., Kumar S., Ali M., Khan A., Singh V., Murti S. (2013) Host range, susceptibility period of Curvularia lunata causing leaf spot of black gram and germplasm screening. Agriways 1: 142-146.

Loper J.E., Schroth M.N. (1986) Influence of bacterial sources of indole-3-acetic acid on root elongation of sugarbeet. Phytopathol. 76: 386-389.

Mittal J., Sharma S.S., Batra A. (2014) Tinospora cordifolia: a multipurpose medicinal plant. J. Med. Plant Studies 2: $32-47$.

Murillo-Williams A., Munkvold G.P. (2008) Systemic infection by Fusarium verticillioides in maize plants grown under three temperature regimes. Plant Diseases. 92: 1695 -1700. DOI: 10.1094/PDIS-92-12-1695.

Nautiyal C.S. (1999) An efficient microbiological growth medium for screening phosphate-solubilizing microorganisms. FEMS Microbiol. Lett. 170: 265-270.

Panwar M., Tewari R., Gulati A., Nayyar H. (2016) Indigenous salt-tolerant rhizobacterium Pantoea dispersa (PSB3) reduces sodium uptake and mitigates the effects of salt 
stress on growth and yield of chickpea. Acta Physiol. Plant. 38(12): 278.

Penrose D.M., Glick B.R. (2003) Methods for isolating and characterizing ACC deaminase-containing plant growth promoting rhizobacteria. Plant Physiol. 118: 10-15.

Praveen Kumar G., Mir Hassan Ahmed S. K., Desai S., Leo Daniel Amalraj E., Rasul A. (2014) In vitro screening for abiotic stress tolerance in potent biocontrol and plant growth promoting strains of Pseudomonas and Bacillus. Int. J. Bacteriol. doi: 10.1155/2014/195946.

Rangarajan S., Saleen L.M., Nair S.(2002) Diversity of Pseudomonas spp. isolated from rice rhizosphere populations grown along a salinity gradient. Microbial. Ecol. 43: 280 -289 .

Reetha A.K., Pavani S.L., Mohan S. (2014) Hydrogen cyanide production ability by bacterial antagonist and their antibiotics inhibition potential on Macrophomina phaseolina (Tassi.) Goid. Int. J. Curr. Microbiol. Appl. Sci. 3(5): 172-178.

Sharan A., Shikha D.N.S., Gaur R. (2008) Xanthomonas campestris, a novel stress tolerant, phosphate-solubilizing bacterial strain from saline-alkali soils. W. J. Microbiol. Biotechnol. 24: 753-759.

Stackebrandt E., Goebel B.M. (1994) Taxonomic note: a place for DNA-DNA reassociation and $16 S r R N A$ sequence analysis in the present species definition in bacteriology. Int. J. Sys. Bacteriol. 44: 846-849.

Tsavkelova E.A., Cherdyntseva T.A., Botina S.G., Netrusov A.I. (2007) Bacteria associated with orchid roots and microbial production of auxin. Microbiol. Res. 162: 69-76.
Vardharajula S., Ali S.Z., Grover M., Reddy G., Bandi V. (2011) Drought-tolerant plant growth promoting Bacillus spp.: effect on growth, osmolytes, and antioxidant status of maize under drought stress. J. Plant Interact. 6: 1-14.

Vyas P., Gulati A. (2009) Organic acid production in vitro and plant growth promotion in maize under controlled environment by phosphate-solubilizing fluorescent Pseudomonas. BMC Microbiol. 9: 174.

Vyas P., Rahi P., Gulati A. (2009) Stress tolerance and genetic variability of phosphate-solubilizing fluorescent Pseudomonas from the cold desert of the trans-Himalayas. Microbial. Ecol. 58: 425-434.

Vyas P., Joshi R., Sharma K.C., Rahi P., Gulati A., Gulati A. (2010) Cold-adapted and rhizosphere-competent strain of Rahnella sp. with broad-spectrum plant growth-promotion potential. J. Microbiol. Biotechnol. 20: 1724-1734. doi: 10.4014/jmb.1007.07030.

Wang L.T., Lee F.L., Tai C.J., Kasai H. (2007) Comparison of gyrB gene sequences, 16S rRNA gene sequences and DNA-DNA hybridization in the Bacillus subtilis group. Int. J. Sys. Evol. Microbiol. 57: 1846-1850.

Wang Q., Dodd I.C., Belimov A.A., Jiang F. (2016) Rhizosphere bacteria containing 1-aminocyclopropane-1carboxylate deaminase increase growth and photosynthesis of pea plants under salt stress by limiting $\mathrm{Na}+$ accumulation. Funct. Plant Biol. 43: 161-172.

Weisburg W.G., Barns S.M., Pelletier D.A., Lane D.J. (1991) $16 S$ ribosomal DNA amplification for phylogenetic study. J. Bacteriol. 173: 697-703. 